\title{
PENELUSURAN MINAT BAKAT UNTUK SISWA SMA SK DI JAKARTA BARAT
}

\author{
Kiky Dwi Hapsari Saraswati ${ }^{1}$, Jessica Chandhika², dan Daniel Lie ${ }^{3}$ \\ ${ }^{1}$ Fakultas Psikologi, Universitas Tarumanagara Jakarta \\ Surel: kikys@fpsi.untar.ac.id \\ ${ }^{2}$ Fakultas Psikologi, Universitas Tarumanagara Jakarta \\ Surel: jessica@fpsi.untar.ac.id \\ ${ }^{3}$ Fakultas Psikologi, Universitas Tarumanagara Jakarta \\ Surel: daniell@fpsi.untar.ac.id
}

\begin{abstract}
Adolescence is a transitional period from the development of children to adults. At this stage of development, selecting a university course is a difficult task for students because they are still unsure about their own identity. Many of them still like to try out and follow what their friends do. The choice of university course is very important because it determines the continuity of the students' studies in the university. Currently, SK High School does not have a psychologist in helping the students to understand their own aptitude and interest. Hence, a community service activity based on aptitude and interest test was carried out and conducted by a group of lecturers from Faculty of Psychology Universitas Tarumanagara (who are also psychologists). This aptitude and interest test was attended by 20 high school students of class XII and they completed five tests (Culture Fair Intelligence Test; Tes Administrasi, Keuangan, dan Dagang; Rothwell Miller Interest Blank; Pemeriksaan Teknik Pasti; Tes House Tree Person) to measure three aspects (intelligence, aptitude, and interest). Results were shown in the report format, consisting of description of the three aspects; a summary of students'strengths, weaknesses, and suggestions for improvements; and recommendation university course. This report can be used by students, parents, and the school as a reference to assist students in selecting the most appropriate university course.
\end{abstract}

Keywords: Aptitude Test, Interest Test, High School, Students

\begin{abstract}
ABSTRAK
Masa remaja merupakan masa peralihan dari tahap perkembangan anak-anak menjadi dewasa. Di tahap perkembangan ini, pemilihan jurusan menjadi hal yang sulit bagi para siswa karena mereka masih belum memiliki ketetapan mengenai jati diri mereka sendiri. Banyak di antara mereka yang masih suka coba-coba dan ikut-ikutan teman. Pemilihan jurusan di perguruan tinggi sendiri merupakan hal yang sangat penting karena akan menentukan kelangsungan studi para siswa di perguruan tinggi. Sekarang ini Sekolah Menengah Atas (SMA) SK tidak memiliki psikolog yang dapat membantu para siswa untuk memberikan gambaran mengenai minat-bakat mereka. Oleh karena itu, kegiatan pengabdian kepada masyarakat berbasis penelusuran bakat-minat dilaksanakan dan dilakukan oleh dosen Fakultas Psikologi Universitas Tarumanagara yang juga berprofesi sebagai psikolog. Tes bakat dan minat diikuti oleh 20 siswa SMA kelas XII dan mereka menyelesaikan lima tes (Culture Fair Intelligence Test; Tes Administrasi, Keuangan, dan Dagang; Rothwell Miller Interest Blank; Pemeriksaan Teknik Pasti; serta Tes House Tree Person) untuk mengukur tiga aspek yaitu inteligensi, minat dan bakat. Hasil ditunjukkan dalam bentuk laporan yang terdiri dari gambaran pada ketiga aspek tersebut; ringkasan singkat mengenai kekuatan, kelemahan, dan saran peningkatan untuk mahasiswa tersebut; dan rekomendasi jurusan di perguruan tinggi. Laporan dapat digunakan oleh siswa, orang tua, dan pihak sekolah sebagai referensi untuk membantu para mahasiswa dalam memilih jurusan di penguruan tinggi.
\end{abstract}

Kata Kunci: Tes Minat, Tes Bakat, SMA, Siswa

\section{PENDAHULUAN}

Masa remaja merupakan masa peralihan dari tahap perkembangan anak-anak menjadi dewasa. Pada masa ini banyak remaja yang mengalami pergejolakan baik secara fisik maupun mental. Dalam konsep perkembangan, seorang remaja ditandai dengan tiga perubahan, yakni (a) 
perubahan fisik, (b) perkembangan kognitif yang ditandai dengan perubahan dari masa operasi konkrit menjadi operasi formal, dan (c) perkembangan psikososial yang ditandai pengembangan identitas diri (Santrock, 2012).

Papalia (2009) menyebutkan bahwa perkembangan fisik yang terjadi ditandai dengan kematangan alat reproduksi baik pada laki-laki dan perempuan. Hal ini juga terkait dengan kadar hormon estrogen yang meningkat pada perempuan dan progresteron pada laki-laki. Kedua hormon ini akan berperan sangat berbeda pada tubuh laki-laki dan perempuan. Hormon estrogen akan berperan dalam pertumbuhan alat kelamin wanita terutama sel telur dan juga membesarnya payudara. Hormon testosteron pada laki-laki akan merangsang pertumbuhan alat kelamin pria, massa otot dan munculnya rambut tubuh di bagian dada. Selain perubahan dari organ reproduksi yang merupakan tanda perubahan primer secara seksual, remaja juga mengalami perubahan seksual sekunder yakni tanda fisiologis kematangan seksual yang tidak terkait langsung dengan organ reproduksi seperti munculnya perubahan suara, tekstur kulit, dan massa otot.

Piaget (dalam Papalia, 2009) mengungkapkan bahwa perkembangan kognitif meliputi kemampuan berpikir abstrak, dan menggunakan konsep-konsep mental yang lebih kompleks daripada sekadar berpikir secara konkrit. Piaget (dalam Papalia, 2009) menyatakan bahwa ini merupakan tahap pemikiran operasional formal. Perubahan lainnya yang terjadi pada masa remaja berhubungan dengan egosentrisme remaja (King, 2010). Merujuk kepada Piaget (dalam Papalia, 2009), remaja memasuki level tertinggi perkembangan kognitif, yaitu operasional formal ketika mereka mengembangkan kemampuan berpikir abstrak. Perkembangan ini memberikan cara baru yang lebih fleksibel kepada mereka untuk mengolah informasi. Dengan demikian di masa ini remaja seharusnya mampu untuk menemukan makna yang lebih mendalam dan melihat sesuatu yang tersirat ketika membaca atau mendengar suatu informasi. Remaja juga seharusnya sudah mampu untuk berpikir dalam kerangka asumsi, sehingga memiliki kemampuan untuk menyusun serta menguji asumsi tersebut. Di tahap ini pula seorang remaja seharusnya memiliki perencanaan yang lebih matang dan dapat menyusun penyelesaian masalah yang realistis untuk diterapkan dalam menjawab tantangan yang dihadapinya.

Perkembangan psikososial merupakan aspek perkembangan yang meliputi perkembangan emosional dan sosial, kognitif, serta moral. Menurut Erikson (dalam Santrock, 2012), tahap perkembangan remaja di usia 17-18 tahun masuk ke dalam tahap perkembangan identity versus role confusion. Pada tahap ini, seorang remaja akan mencoba banyak hal untuk mengetahui jati diri mereka sebenarnya, dan biasanya mereka akan mencari teman yang memiliki kesamaan dengan dirinya untuk melewati hal tersebut. Seorang remaja mengenali segala potensi kelebihan dan kelemahannya, dan berusaha untuk menjadi diri sendiri. Erikson (dalam Santrock, 2012) menyatakan bahwa seorang remaja akhir akan memiliki minat yang mendalam untuk menekankan fungsi intelek mereka, remaja juga akan berusaha untuk dapat diterima dalam lingkungannya, mengetahui identitas seksualnya dan mantap terhadap pilihan identitas seksualnya, mulai lebih dapat memahami kondisi orang lain dan munculnya konsep diri yang bisa memisahkan diri dengan lingkungannya.

Dapat dikatakan bahwa remaja mengalami berbagai macam perubahan yang terjadi secara sekaligus yang membuat mereka mengalami beberapa fase yang membuat mereka mengalami pergejolakan. Hal ini disebabkan oleh remaja harus menyelesaikan tugas perkembangan mereka dengan baik agar dapat menjadi manusia dewasa yang mampu untuk mengatasi berbagai permasalahan yang ada. Di tahap remaja akhir ini juga, seorang remaha harus mengambil ebebrapa keputusan penting yang akan mempengaruhi kehidupan mereka di masa yang akan datang. 
Siswa kelas XII Sekolah Menengah Atas (SMA) merupakan siswa berusia 17-18 tahun yang berada di tahapan remaja akhir dan sesaat lagi akan masuk ke usia dewasa muda. Remaja yang memiliki identitas diri yang matang ditandai dengan keberhasilan mencapai konsep diri, kepercayaan diri, rasa tanggung jawab terhadap diri sendiri maupun masa depan hidupnya (Santrock, 2012). Di masa ini, remaja harus sudah menentukan apakah dirinya akan melanjutkan ke pendidikan yang lebih tinggi atau memilih untuk langsung bekerja. Bagi yang memilih untuk melanjutkan pendidikan, pemilihan jurusan yang tepat akan sangat penting karena terkait dengan waktu dan biaya finansial yang harus ditanggung jika masa studi tersebut lebih panjang dari yang seharusnya atau tidak selesai di tengah jalan dan memutuskan untuk pindah ke jurusan lain. Waktu studi dapat menjadi lebih panjang jika mahasiswa tidak fokus terhadap kuliahnya dan tidak berusaha untuk lulus dengan baik di setiap mata kuliah yang diambilnya. Hal ini tentu berdampak pada biaya yang harus dikeluarkan untuk masa studi yang panjang ini.

Di tahap perkembangan remaja akhir pemilihan jurusan menjadi hal yang sulit bagi para siswa karena mereka masih belum memiliki ketetapan mengenai jati diri mereka sendiri. Banyak di antara mereka yang masih suka coba-coba dan ikut-ikutan teman. Pemilihan jurusan di perguruan tinggi sendiri merupakan hal yang sangat penting karena akan menentukan kelangsungan studi para siswa di perguruan tinggi. Banyak di antara mereka yang masih cobacoba untuk mengetahui apa yang paling sesuai bagi diri mereka. Mungkin saja seorang siswa melakukan proses peniruan orang lain yang dianggap idolanya, namun kemudian ia akan dapat memiliki gaya kehidupan pribadi yang khas dan berbeda dengan orang lain. Sebaliknya, remaja yang tidak mampu mencapai identitas diri, maka ia dianggap tidak matang dan sulit menjadi pribadi yang mandiri. Hal ini dinamakan pribadi yang sedang bingung mencari identitas atau identity confussion (Santrock, 2012).

Memilih jurusan yang tepat menjadi sangat penting karena hal ini akan mempengaruhi motivasi siswa dalam menyelesaikan studi mereka di perguruan tinggi. Motivasi merupakan dorongan seseorang untuk melakukan sesuatu dalam mencapai tujuan yang ingin dicapainya (Santrock, 2012). Dapat dikatakan bahwa motivasi sangat berpengaruh terhadap prestasi belajar. Siswa yang memiliki motivasi belajar yang tinggi akan menyadari dan memahami tujuan yang akan dicapainya di kemudian hari, sehingga akan giat untuk belajar, tekun dan tidak mudah menyerah dalam upaya untuk meningkatkan prestasi belajar. Sebaliknya, siswa yang memiliki motivasi yang rendah, cenderung tidak peduli, tidak fokus, mudah putus asa, sehingga perhatian siswa tidak fokus pada pelajaran

Terdapat dua jenis motif, yaitu (a) motif internal dan (b) motif eksternal. Motif internal cenderung lebih dapat bertahan lama daripada motif eksternal (Santrock, 2012). Motif internal terdiri dari empat faktor, yakni (a) self determination (kemampuan untuk menetukan tujuan diri sendiri), (b) curiosity (kecenderungan untuk mengetahui dan menguasai sesuatu yang cukup besar dari dalam diri sendiri), (c) challenge (suatu kesempatan untuk memperoleh sesuatu sesuai dengan kemampuan diri sendiri), dan (d) effort (suatu keahlian yang dipergunakan untuk mencapai sesuatu sesuai dengan harapannya). Mempelajari sesuatu agar dapat mencapai keberhasilan dengan baik dibutuhkan motivasi yang tinggi. Motivasi yang berasal dari luar (motif eksternal) cenderung tidak akan bertahan lama, karena bila stimulasi luar tersebut sudah hilang atau tidak ada lagi, maka seseorang cenderung akan menurunkan semangat belajarnya (Santrock, 2012). Dengan demikian daya tahan menghadapi suatu tantangan tidak akan efektif dan tidak mencapai sasaran belajarnya. Pada akhirnya hal ini akan berdampak pada prestasi akademik siswa dan dapat membuat masa studi siswa di perguruan tinggi menjadi lebih panjang. Hal ini tentu akan berdampak panjang di mana siswa tidak dapat memulai karirnya secara profesional karena masa studi yang panjang dan prestasi akademik yang tidak maksimal. 
Beberapa situasi yang dapat membuat seorang siswa salah memilih jurusan adalah ikut-ikutan teman atau secara terpaksa mengambil jurusan yang dipilihkan oleh orang tua (Nimda, 2019). Salah memilih jurusan karena tidak sesuai dengan bakat dan minat siswa akan berdampak negatif (Awaliyah \& Murdaningsih, 2019). Beberapa dampak yang dapat terjadi adalah kesulitan untuk memahami materi yang diberikan. Proses pembelajaran yang dipaksakan akan sulit dipahami secara kognitif karena siswa dalam mengalami mental block. Perasaan negatif seperti marah, sedih dan kesal juga turut berperan dalam proses belajar yang tidak maksimal karena akan menghambat kinerja kognitif dan menurunkan kadar motivasi (Khadijah, 2016). Hal ini juga dapat diperparah dengan kondisi siswa dengan kemampuan kognitif yang pas-pasan dan secara terpaksa atau memaksa diri memilih jurusan yang banyak menggunakan kemampuan kognitif yang lebih tinggi daripada jurusan lainnya. Misalnya, jurusan seperti kedokteran dan teknik tentu membutuhkan kemampuan berpikir kognitif abstrak yang lebih tinggi daripada jurusan seni dan desain. Masalah akademis yang dapat terjadi jika salah mengambil pilihan, seperti prestasi yang tidak optimal, pengulangan mata kuliah yang berdampak bertambahnya waktu dan biaya, kesulitan memahami materi, kesulitan memecahkan persoalan, ketidakmampuan untuk mandiri dalam belajar, dan akhirnya adalah rendahnya nilai indeks prestasi (Irma, 2018). Selain itu, salah memilih jurusan bisa mempengaruhi motivasi belajar dan tingkat kehadiran. Kalau makin sering tidak masuk kuliah, makin sulit memahami materi, makin tidak suka dengan perkuliahannya akhirnya makin sering bolos. Padahal, tingkat kehadiran mempengaruhi nilai. Oleh karena itu memilih jurusan yang sangat sesuai dengan bakat dan minat siswa akan sangat penting dan sangat signifikan dampaknya pada masa studi siswa di perguruan tinggi (Lestari, 2010).

Pencapaian hasil prestasi belajar yang baik seorang mahasiswa juga dipengaruhi oleh faktor lain di luar motivasi, seperti kecerdasan, bakat, minat, cara belajar, lingkungan keluarga, dan sekolah. Adapun faktor yang menghambat prestasi belajar mahasiswa antara lain adalah kurangnya disiplin diri dan disiplin dalam belajar, baik di rumah maupun di sekolah, seperti kurangnya kesadaran diri untuk belajar sendiri, kurang giat belajar, kurang banyak waktu untuk belajar, kurang teratur belajar, ada rasa malas belajar di rumah pada sore atau malam hari, banyak waktu kosong tidak dimanfaatkan dengan baik (Sunarsih, 2009).

Masalah-masalah tersebut di atas dapat dicegah dengan memberikan informasi yang komprehensif mengenai minat dan bakat yang dimiliki oleh tiap siswa. Bakat adalah kemampuan untuk belajar (Ramsay, 2008). Reed dan Wolniak (2005) mendefinisikan bakat sebagai karakteristik pribadi yang mengarahkan seseorang untuk meraih kesuksesan, sedangkan minat adalah interaksi antara keinginan, harapan, pengalaman atau kebutuhan yang menggerakan seseorang untuk menyukai hal tertentu. Dengan dimilikinya informasi yang komprehensif tentang minat dan bakat, diharapkan siswa tidak keliru dalam memilih program studi. Winkel (2005) menjelaskan bahwa kekeliruan dalam memilih program studi di tingkat pendidikan lanjutan atas dan pendidikan tinggi dapat membawa akibat fatal bagi kehidupan seseorang. Beberapa dampak kepada para pelajar sebagai implikasi dari perilaku tersebut di atas adalah rendahnya motivasi yang berujung pada prestasi akademik serta rendahnya daya saing bangsa di tengah-tengah bangsa lain di dunia. Oleh karena itu, kekeliruan demikian sedapat mungkin dihindari oleh siswa dengan melakukan penelusuran minat dan bakat siswa melalui tes psikologis sebelum mereka memilih jurusan di perguruan tinggi.

Pengertian tes menurut Suryabrata (1993) adalah pertanyaan-pertanyaan yang harus dijawab dan atau perintah-perintah yang harus dijalankan yang berdasar atas bagaimana testee menjawab. Anastasi (1997) mengemukakan bahwa esensi dari tes merupakan penentuan yang obyektif dan terstandardisasikan. Bakat seseorang dapat diukur dengan tes bakat. Tes bakat 
adalah tes yang dirancang untuk mrngukur kemampuan potensial seseorang dalam suatu jenis aktivitas tertentu dan dalam rentang tertentu. Faktor-faktor yang diungkap oleh tes bakat adalah: (a) kemampuan verbal, adalah kemampuan memahami dan menggunakan bahasa baik lisan ataupun tulisan; (b) kemampuan numerik, adalah kemampuan ketepatan dan ketelitian memecahkan masalah aritmatik atau konsep dasar berhitung; (c) kemampuan spasial, adalah kemampuan merancang benda secara tepat; (d) kemampuan perceptual, adalah kemampuan mengamati dan memahami gambar dua dimensi menjadi bentuk tiga dimensi; (e) kemampuan reasoning, adalah kemampuan memecahkan suatu masalah; (f) kemampuan mekanik, adalah kemampuan memahami konsep mekanik dan fisika; (g) kemampuan memori, adalah kemampuan mengingat; (h) kemampuan clerical, adalah kemampuan bekerja di bidang administrasi; (i) kreativitas, adalah kemampuan menghasilkan sesuatu yang baru dan menunjukkan hal yang tidak biasa atau istimewa; (j) kecepatan kerja, adalah kemampuan bekerja secara cepat terutama untuk pekerjaan yang rutin; (k) ketelitian kerja, adalah kemampuan bekerja dengan teliti; (1) ketahanan kerja, adalah kemampuan bekerja secara konsisten (Nuraeni, 2012).

Tes minat mengungkapkan reaksi seseorang terhadap berbagai situasi yang secara keseluruhan akan mencerminkan minatnya. Minat yang terungkap melalui tes minat ini seringkali menunjukkan minat yang lebih mewakili daripada minat yang sekedar dinyatakan yang biasanya bukan merupakan minat yang sesungguhnya. Pada umumnya hasil tes minat digunakan dalam empat bidang terapan yaitu (a) konseling karier bagi siswa sekolah lanjutan, (b) konseling pekerjaan bagi karyawan, (c) penjurusan siswa sekolah lanjutan atau mahasiswa dan (d) perencanaan bacaan dalam pendidikan dan latihan (Nuraeni, 2012).

Berdasarkan pemaparan di atas, dapat disimpulkan bahwa mengetahui bakat dan minat bagi siswa SMA sangat penting khususnya untuk keperluan pemilihan jurusan di perguruan tinggi nantinya. Proses ini dapat dilakukan dengan pelaksanaan tes bakat dan minat pada siswa yang bersangkutan dibawah naugan psikolog. Salah satu SMA di Jakarta Barat (SMA SK) tidak memiliki psikolog yang dapat membantu mahasiswanya untuk menggali potensi dan minatnya untuk keperluan pemilihan jurusan yang sesuai bagi mereka di tingkat penguruan tinggi. Oleh karena itu, kegiatan Pengabdian Kepada Masyarakat (PKM) ini dilaksanakan oleh tim pelaksana yang terdiri dari dosen-dosen Fakultas Psikologi Universitas Tarumanagara yang juga berprofesi sebagai psikolog dan memiliki Surat Izin Praktik Psikolog, akan menelusuri minat dan bakat siswa SMA SK. Kegiatan ini diharapkan dapat membantu siswa SMA SK dalam memilih jurusan yang tepat bagi diri sendiri tanpa terpengaruh teman, sehingga dapat berprestasi di masa kuliah dan menyelesaikan masa studi dengan tepat waktu.

\section{METODE PELAKSANAAN PKM}

Kegiatan diawali dengan dilakukannya diskusi antara ketua tim pelaksana dengan pihak SMA SK mengenai rencana kegiatan PKM ini. Diskusi ini meliputi: (a) manfaat yang dapat diterima baik bagi para siswa, orang tua siswa, sekolah; (b) waktu yang akan dialokasikan untuk pelaksanaan kegiatan; dan (c) kelengkapan logistik yang perlu disiapkan oleh pihak sekolah dan tim pelaksana untuk mendukung kesusksesan pelaksanaan kegiatan ini. Setelah kedua pihak menyetujui masing-masing hak dan kewajiban, dibuatlah surat kerja sama yang telah ditandatangani oleh kedua pihak.

Pada hari Senin, 16 September 2019, tes bakat dan minat dilakukan oleh tim pelaksana dengan dibantu oleh dua mahasiswa Fakultas Psikologi Universitas Tarumanagara. Pelaksanaan tes berlangsung dari jam 08.00 hingga pukul 12.00. Kegiatan ini dilaksanakan di satu ruang kelas yang telah disiapkan dari pihak SMA SK dan diikuti oleh 20 siswa (9 perempuan, 11 laki-laki, $M$ $=17.1$ tahun). Setiap siswa menyelesaikan lima tes (Culture Fair Intelligence Test; Tes 
Administrasi, Keuangan, dan Dagang; Rothwell Miller Interest Blank; Pemeriksaan Teknik Pasti; Tes House Tree Person). Pelaksanaan tes berjalan dengan baik dan sesuai rencana dikarekanakan seluruh siswa menyelesaikan seluruh tes sesuai instruksi yang diberikan dan dengan tepat waktu.

Kegiatan selanjutnya yaitu melakukan proses (a) skoring, (b) interpretasi, dan (c) pembuatan laporan. Proses skoring dilakukan dengan cara mencocokkan jawaban siswa pada masing-masing tes dengan kunci jawabannya. Skor akhir didapatkan dengan membandingkan skor mentah (raw score) dengan norma pada masing-masing tes. Setelah itu, psikolog mengintegrasikan seluruh hasil tes, sehingga didapatkan satu gambaran mengenai bakat siswa tersebut. Psikolog juga membandingkan bakat siswa dengan minat yang dimilikinya. Setelah mendapatkan informasi tersebut, psikolog membuat laporan yang dilengkapi dengan rekomendasi jurusan yang dapat dipilih oleh setiap siswa berdasarkan format yang telah disusun oleh Tim Pelaksana. Laporan yang telah dibuat dikirimkan kepada Kepala SMA SK yang selanjutnya diteruskan kepada orang tua siswa pada saat pembagian raport tengah semester ganjil di bulan Oktober 2019.

\section{HASIL DAN PEMBAHASAN}

Dalam proses pemeriksaan bakat dan minat ini, setiap siswa diminta untuk mengerjakan serangkaian tes psikologi untuk mengungkap tiga aspek, yaitu: (a) inteligensi, (b) bakat dan (c) minat. Aspek inteligensi terdiri dari taraf kecerdasan dan aspek bakat terdiri dari kemampuan berhitung, kemampuan mekanik, kecepatan dan ketelitian, pemahaman dan penalaran. Hasil dari kedua aspek tersebut dilaporkan dalam lima kategori, yakni: (a) rendah, (b) kurang, (c) cukup, (d) baik, dan (e) tinggi. Pada aspek minat, psikolog menuliskan dua kategori (outdoor[outd], mechanical[mech], computational[comp], scientific[scie], personal contact[pers], aesthetic[aest], literary[lite], musical[musi], social service[soci], clerical[cler], practical[prac], medical[medi]) pekerjaan yang paling diminati oleh siswa. Selain itu, psikolog yang tergabung dalam Tim Pelaksana juga menuliskan analisis singkat (terkait kekuatan, kelemahan, dan saran untuk peningkatannya) dan jurusan perguruan tinggi yang direkomendasikan untuk siswa yang bersangkutan. Contoh rekapitulasi laporan yang dihasilkan dapat dilihat pada Tabel 1.

Tabel 1. Contoh rekapitulasi laporan tes minat dan bakat pada siswa SMA SK

\begin{tabular}{|c|c|c|c|c|c|c|c|c|c|}
\hline \multicolumn{10}{|c|}{ Hasil Pemeriksaan } \\
\hline & spek & Inteligensi & & & Bakat & & & Minat & \\
\hline No & Siswa & Kecerdasan & Berhitung & Mekanik & $\begin{array}{c}\text { Kecepatan } \\
\& \\
\text { Ketelitian }\end{array}$ & Pemahaman & Penalaran & - & $\begin{array}{c}\text { Saran } \\
\text { Jurusan }\end{array}$ \\
\hline 01 & $\mathrm{AC}$ & Cukup & Cukup & Cukup & Kurang & Cukup & Cukup & $\begin{array}{l}\text { Prac } \\
\text { Soci }\end{array}$ & $\begin{array}{c}\text { Psikologi } \\
\text { Teknik Industri }\end{array}$ \\
\hline 02 & $\mathrm{~S}$ & Kurang & Cukup & Cukup & Kurang & Cukup & Cukup & $\begin{array}{l}\text { Cler } \\
\text { Prac }\end{array}$ & $\begin{array}{c}\text { Mjm. Operasional } \\
\text { Admin Bisnis }\end{array}$ \\
\hline 03 & $\mathrm{~T}$ & Cukup & Kurang & Kurang & Kurang & Kurang & Cukup & $\begin{array}{l}\text { Aes } \\
\text { Soci }\end{array}$ & $\begin{array}{c}\text { Seni Rupa/Desain } \\
\text { Psikologi }\end{array}$ \\
\hline 04 & AY & Cukup & Cukup & Cukup & Kurang & Cukup & Cukup & $\begin{array}{l}\text { Soci } \\
\text { Outd }\end{array}$ & $\begin{array}{c}\text { Manajemen SDM } \\
\text { Teknik Industri }\end{array}$ \\
\hline 05 & $\mathrm{BW}$ & Kurang & Cukup & Cukup & Kurang & Kurang & Cukup & $\begin{array}{l}\text { Aes } \\
\text { Soci }\end{array}$ & $\begin{array}{l}\text { Seni Rupa/Desain } \\
\text { Mjm. Pemasaran }\end{array}$ \\
\hline
\end{tabular}


Berdasarkan informasi pada Tabel 1 didapatkan gambaran umum mengenai bakat dan minat siswa SMA SK. Bakat mereka tersebar orientasinya ke bidang seperti (a) berhitung dan (b) mekanik. Minat para siswa terarah pada bidang yakni (a) practical dan (b) social service.

Laporan siswa dibuat berdasarkan dari integrasi hasil serangkaian tes yang diberikan. Jawaban siswa dicocokkan dengan kunci jawaban dan skor final didapatkan dengan membandingkannya dengan norma yang ada. Hal ini sesuai dengan apa yang diutarakan oleh Anastasi (1997) yang menjelaskan bahwa tes merupakan penentuan yang obyektif dan terstandardisasikan. Selain itu, tes bakat yang dilaksanakan pada siswa SMA SK juga sesuai dengan apa yang dijelaskan oleh Nuraeni (2012) bahwa tes bakat menguji kemampuan dan ketelitian siswa. Dengan dilaksanakan tes bakat ini, siswa mengetahui bakat mereka dan menurut Nuraeni (2012) ada dua tujuan yang didapatkan apabila siswa mengetahuinya. Pertama, dengan mengetahui bakat seseorang maka akan dipahami potensi yang ada pada diri seseorang. Dengan demikian dapat membantu untuk menganalisis permasalahan yang dihadapi (mengetahui kekuatan dan kelemahan pada diri sendiri) Kedua, untuk memprediksi kemungkinan kesuksesan atau kegagalan seseorang dalam bidang tertentu di masa depan. Prediksi meliputi seleksi, penempatan, dan klasifikasi. Dengan mengetahui minat dan bakat siswa, siswa secara langsung mampu mengetahui gambaran mengenai dirinya, sehingga mencengah kekeliruhan dalam pemilihan jurusan (Winkel, 2005).

Walaupun kegiatan ini telah berjalan secara lancar dan sukses, akan lebih bermanfaat lagi bagi siswa jika psikolog dapat melakukan wawancara mandiri dengan siswa (Nahooda, 2015). Dalam sesi wawancara ini, psikolog memiliki tugas untuk menakar apakah siswa sudah memiliki rasionalitas dalam memandang permasalahan pemilihan jurusan yang sedang dihadapinya. Klarifikasi pemasalahan pemilihan jurusan memberikan gambaran bahwa masalah-masalah yang ada disebabkan seseorang tidak memiliki kejelasan kognisi dan tugas psikolog adalah untuk melakukan penjelasan kepada siswa dengan harapan pola pikir yang tidak rasional dapat berubah menjadi lebih rasional, sehingga meningkatnya self-efficacy (keyakinan seseorang untuk mampu menyelesaikan suatu tugas dengan kemampuan yang dimilikinya) dari siswa tersebut (Ingarianti \& Purwaningrum, 2018).

Contoh ketidakjelasan kognisi yang dijelaskan oleh Ingarianti dan Purwaningrum (2018) adalah (a) kekeliruhan pemeroleh informasi - informasi yang didapatkan siswa tidak diterima, dicerna dan dimanfaatkan sebagaimana yang dimaksud oleh pemberi informasi, sehingga tidak tepat pada sasaran, diartikan dengan cara yang salah, dan tidak melalui proses kroscek dengan sumber informasi lainnya; (b) anggapan yang salah akan kemampuan dirinya - kadang siswa memiliki pengalaman terdahulu yang memungkinkan individu menganggap semua kegagalan dapat terjadi padanya hanya dengan melihat orang lain gagal melewati suatu tes dan wawancara; (c) filtrasi hal ini berhubungan dengan bagaimana individu memandang satu jurusan hanya dari satu sisi saja (sisi baik atau sisi buruk). Padahal sebagai individu yang sehat, penting untuk melihat satu jurusan secara menyeluruh dari segala aspek sehingga dapat terlihat bagaimana gambaran dirinya mengenai jurusan yang ingin dipilih secara benar.

\section{KESIMPULAN DAN SARAN}

Terdapat empat kesimpulan dalam kegiatan PKM ini. Pertama, kegiatan penelusuran minat-bakat terhadap siswa SMA perlu dilakukan dan hasilnya sangat berguna bagi para siswa dan orangtua karena dapat membantu kelancaran studi di perguruan tinggi dan dapat mencegah munculnya masalah akibat kekeliruan memilih bidang studi. Kedua, pelaksanaan kegiatan penelusuran bakat-minat di SMA SK berlangsung lancar karena didukung penuh oleh pihak sekolah melalui pemberitahuan kepada para siswa sehingga mereka siap mengikuti kegiatan tersebut. Selain itu kerjasama yang ditunjukkan para siswa juga turut membantu kelancaran kegiatan tersebut 
sehingga pemanfaatan waktu berlangsung efisien. Ketiga, hasil kegiatan menunjukkan gambaran yang normatif, dalam arti gambaran bakat-minat siswa SMA SK sesuai dengan teori. Taraf kecerdasan umum para siswa di SMA SK juga menunjukkan taraf yang cukup sehingga para siswanya diharapkan dapat melanjutkan ke tingkat pendidikan tinggi (akademi/universitas). Keempat, tim yang melaksanakan tugas penelusuran bakat-minat memperlihatkan kerja sama yang baik, saling membantu, dan saling mengingatkan sehingga semua tugas dapat diselesaikan dengan baik.

Selanjutnya, terdapat dua saran yang dapat diberikan untuk kegiatan PKM selanjutnya. Pertama, meminta bantuan mitra untuk memberikan gambaran atau penjelasan kepada pihak sekolah lainnya betapa pentingnya pemeriksaan bakat dan minat ini untuk siswa sebelum mereka memilih jurusan di perguruan tinggi. Kedua, kegiatan penelusuran bakat-minat dapat dilaksanakan pada sekolah-sekolah lain yang membutuhkan dan dapat dilakukan oleh tim pelaksana. Kegiatan ini juga dapat dijadikan sarana untuk mempromosikan Universitas Tarumanagara kepada masyarakat luas.

\section{Ucapan Terima Kasih}

Penulis mengucapkan terima kasih kepada pihak SMA SK yang telah memberikan dukungan penuh terhadap kegiatan tes minat dan bakat ini, dengan menyediakan fasilitas dan segala keperluan pendukung yang dibutuhkan oleh tim pelaksana. Tidak lupa penulis juga mengucapkan banyak terima kasih kepada Lembaga Penelitian dan Pengabdian Masyarakat Universitas Tarumanagara, sehingga kegiatan PKM ini dapat berjalan dengan lancar.

\section{REFERENSI}

Anastasi, A. (1997). Psychological testing, (7 $7^{\text {th }}$ ed.). New Jersey: Prentice Hall.

Awaliyah, G., \& Murdaningsih, D. (2019, Febuari 07). 87 persen mahasiswa mengaku salah pilih jurusan. Diunduh dari https://republika.co.id/berita/pmjuhw368/87-persenmahasiswa-mengaku-salah-pilih-jurusan.

Ingarianti, T. M., \& Purwaningrum, R. (2018). Teori dan praktik konseling karier integratif. Bandung: PT Refika Aditama.

Irma. (2018, November 12). Salah pilih jurusan bisa pengaruhi nilai. Diunduh dari https://metrojambi.com/read/2018/11/12/37218/salah-pilih-jurusan-bisa-pengaruhi-nilai.

Khadijah. (2016). Pengembangan kognitif anak usia dini. Medan: Perdana Publishing.

King, L. (2010). Experience psychology. New York: McGraw-Hill Education.

Lestari, S. (2010). Faktor-faktor yang mempengaruhi minat siswa terhadap pemilihan program studi Pendidikan kewarganegaraaan UNNES (studi penelitian siswa SMA N 2 Batang) (Skripsi). Universitas Negeri Semarang, Semarang.

Nahooda, M. P. (2015). Manajemen pembinaan dan pengmebangan bakat minat siswa di Sekolah Pattanakan Suksa Mulniti Muang Satun Selatan Thailand (Skripsi). Universitas Islam Negeri Walisongo, Semarang.

Nimda. (2019, Januari 30). Jurusan kuliah, pilihan kamu atau orang tua? Diunduh dari https://www.teknik.unpas.ac.id/blogs/jurusan-kuliah-pilihan-kamu-atau-orang-tua/

Nuraeni (2012). Tes psikologi: Tes inteligensi dan tes bakat. Yogyakarta: Purwokerto Press.

Papalia, E. D. (2009). Human development: Perkembangan manusia. Jakarta: Salemba Humanika. 
Ramsay, T. (2008). Advantages of multiple choice aptitude tests, diunduh tanggal 15 Oktober, 2015 dari http://www.ramsaycorp.com/categories/aptitude.asp

Reed, E. J., \& Wolniak, G. C., (2005). Concept of aptitude. Electronic Journal of Sociology, $\begin{array}{lllll}\text { diunduh } & \text { tanggal } & 23 & \text { Februari } & 2007\end{array}$ http://www.sociology.org/content/2005/tier1/reed_wolniak.pdf

Santrock, J. W. (2012). Life-span development. (14 ${ }^{\text {th }}$ ed.). New York: McGraw-Hill Education.

Sunarsih, T. (2010). Hubungan antara motivasi belajar, kemandirian belajar dan bimbingan akademik terhadap prestasi belajar mahasiswa di Stikes A. Yani Yogyakarta (Doctoral dissertation) Universitas Sebelas Maret, Solo.

Suryabrata, S. (1993). Psikologi pendidikan. Jakarta: PT Raya Grafindo Persada.

Winkel, W. S. (2005) Psikologi pengajaran. Yogyakarta: Media Abadi. 